\title{
SOME RHETORICAL PRINCIPLES IN TECHNICAL AND SCIENTIFIC WRITING IN ENGLISH AND IN FRENCH
}

\author{
Candace Sẽguinot
}

\section{Introduction}

In the introduction to their classic Stylistique comparee du francais et de 1 'anglais $(1977: 25)$, Vinay and Darbelnet explain that a comparative study of languages is one way of getting to understand the workings of each individual language. One of the additional advantages of looking at the forms of argumentation and discourse features of science and technology from a comparative perspective is that it's easier then to see the interplay between science, language, and ideology.

\section{Ideology}

To begin with, different language groups do not necessarily view science in the same way, practise science in the same way, or define science in the same way. Since ideological features are marked in the stylistic and rhetorical system, differences in attitude and concept will be reflected in these systems. The ancient Greeks, for example, valued scientific pursuits as a lefsure activity; verification, however, implied work, and work was the domain of slaves. So the reason that practical, mechanical science began in the Middle Ages and observational/ experimental science came even later was not because the scientific and technical knowledge wasn't there to build on; it was because the ideology of the time defined the kind of science that would be done.

Historically, there was a time when science was still viewed as a gentlemanly pursuit in Britain when in France the process of bureaucratization and centralization had already begun. Knight (1986:12) explains the difference metaphorically by comparing the publication of two books on botany in 1789; Jussieu's systeln of plant classification, which was to become the standard for taxonomy in the field, was produced by a Professor in "a research institution with a museum and a great botanical garden" while the Natural History of Selborne was written by Gilbert White, "a country parson with a keen eye for wild life in the fields and woods".

Foucault (1969) has pointed out how a style of enunciation is based on an a priori historique, meaning that there is a commonality of knowledge, a common perception of the way to identify objects of study, and agreement on the way to note perceptions 
through vocabulary and metaphor. The more institutionalized the scientific discipline is, the more the rhetoric of the science will have to make reference to previous work to prove that it is indeed science. In France the social apparatus in scientific institutions is not only strong, but centralized, so French authors need to make reference to the authority that comes from links with the past; in North America there is still this need to establish authority, but it interacts with another ideological strain, namely the cult of personality that is tied to the 'cowboy' or 'local boy makes good' myth. That means that individuals can make much stronger personal claims than their colleagues on the other side of the Atlantic. So that even though both French and English avold first and second person reference in scientific text, and both favour the rhetorical use of the first person plural when there is a first person reference, English still uses more first person singular references than French in scientific articles (Tukia:1983, 41).

However, that does not mean that there is necessarily more freedom in English scientific rhetoric, because science is defined more narrowly in North America. To understand what will be considered science in any given culture at any given time, one has to look at the way the goals of scientific enquiry are defined.

Historically, there have been two approaches: the first, humanism, says that the proper goal for all human enquiry is to investigate matters of essence, of nature, of ultimate knowledge; and the second, experimental and observational study, says that science is the search for plausible explanations for observable phenomena. The ideology that dominates a discipline determines the hidden agenda for that scientific community, and a scientist who wants to be recognized as belonging to the mainstream of that discipline has to address him or herself to that agenda. In North America the observational/experimental method prevalls in most sciences and soclal sciences in both French and in English. In France, on the other hand, the social and human sciences are still generally approached from the humanist tradition.

In some sciences this distinction is complicated by the fact that there is both a research and an applied component. Technology, of course, requires a mixture of both. In medicine, there is a research component and two therapeutic components, pharmacy and clinical practice. Applied components, particularly therapeutic components, involve questions of ethics and institutional authority. Thus the rhetoric of applied science will be different from the rhetoric of the research component. 
Even where ideological systems are the same, the scope of the scientific approach--meaning the objects eligible for study and the appropriate context for using the rhetoric of science--may not be. In France the scientific mystique is very much a power in advertising, particularly in the health and beauty industry; drugstores still look like dispensaries and product descriptions can be much more technical than those found in North America directed toward the consumer, as this example of instructions that come with a nail hardener shows:

ECRINAL DURCISSEUR TRAITANT emploie comme seul principe actif le complexe cystine-kēratine-Acylamino-acides intervenant spécifiquement au niveau de 1 'ongle... ECRINAL DURCISSEUR TRAITANT s'emplole de prëférence sur l'ongle nu; peut également être enployé sur l'ongle verni...

The use of the third person to give directions is a feature of the language of pharmaceuticals in both French and English, but it would not be found in English beauty products. Similarly, a French ad in a popular news magazine, for a product to help prevent hair loss, puts the name of the manufacturer--a laboratory-in focus rather than the name of the product (Dercos Anti-chute) and specifies the chemical composition:

Les Laboratoires d'Anglas ont rëussi à le stabiliser pour l'associer à un acíde amino-soufrè favorable au bon fonctionnement du follicule pileux.

A different use of the scientific persona as a marketing tool In France is the lengthy narrative in ads for beauty products which purport to be scientifically formulated for specific uses. Klorane shampoo has kept this scientific style even in its English marketing:

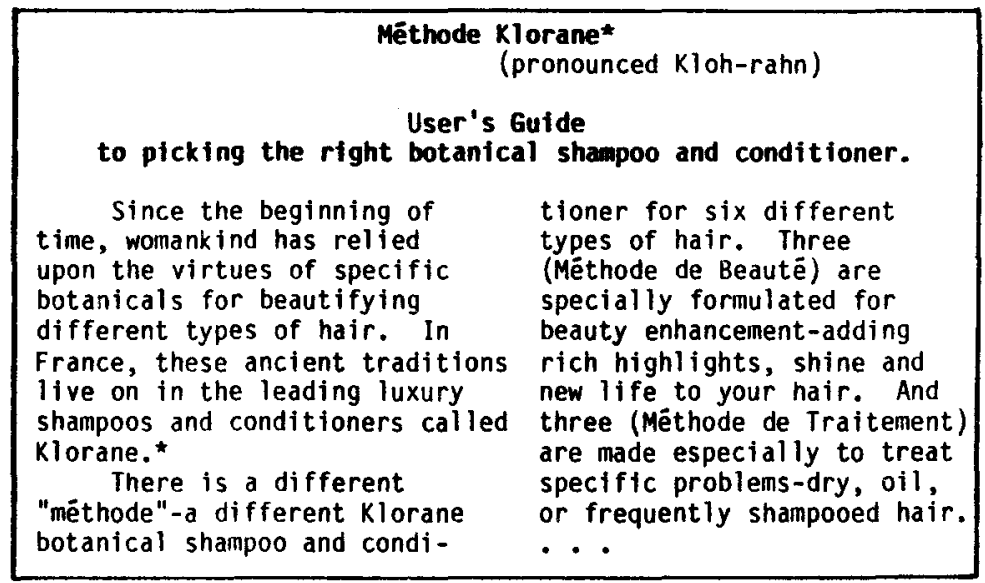


The use of the colon in France to show a scientific voice is another way of marketing through appeal to the authority of science:

Contre la constipation: Herbesan instantanē

What these examples show is that even when we find correspondences between rhetorical devices in English and French, there may be contexts in which the devices are appropriate in one language, but not in the other.

Ail of these factors combine to produce what Bernal (1967: 197-201) has described as the national character of science:

The character of English science is one which can be seen to have persisted ever since the seventeenth century. It is predominantly, as contrasted with German or French science, practical and analogical. In England, more than in any other country, science is felt rather than thought. Imagination is concrete and visual.

In contrast, the history of French science is described as uneven, peaking in the early nineteenth century, then falling behind. Bernal makes a generalization, however, about the presentations of French science which he finds remarkable for their lucidity and beauty.

\section{Language and Science}

The national character of French and English science sounds very similar to the character of their languages. Anyone familiar with contrastive stylistics knows the classic distinctions: the 'genius' of the English language is that it is concrete, precise, explicit, while French is abstract, less constrained by real-time ordering, more prone to generalizing and more implicit (Darbelnet, Vinay and Darbelnet, Guillemin-Flescher). These general tendencies mean that French is more likely to focus meaning in nouns and the English in verbs; French is more prone to use juxtaposition where English marks relations overtly, particularly in the case of co-ordination (Grellet:1985, 176); and French is more likely to use original metaphors where English uses concrete images.

This abstract-concrete distinction is reflected in the broader rhetorical features of English and French text. The French journalist Jean-François Revel has expressed the difference this way: "Chez un Français, 11 y a neuf phrases gënērales et un exemple concret; chez un Américain, neuf exemples concrets pour une généralité." 1 
The kind of argumentation which Revel refers to may account for the findings in comparative rhetoric (Kaplan:1972) in which French speakers writing in English are described as having a tendency to digress. The form of argumentation, in any case, is one which is taught in France and in the classical colleges in Québec through the exercise of the dissertation. So francophones in North America may have learned either this form of rhetoric or the essay writing of English language North American universities in school. The Universitè de Québec à Montrẻal has described the difference between the expectations of these two systems in their Cahter de méthodologie et quide de l'étudiant-e; the dissertation is described as an:

exposè ècrit et raisonnē d'un ensemble de rēflexions sur un sujet donné... La dissertation requiert fidélité aux faits, aux preuves et une logique rigoureuse.

The critical dissertation has a form of organization which presents a thesis, followed by an anti-thesis, followed by a synthesis. The essay is defined (p.107) as a:

texte suivi, de forme libre, au caractère provisoire où l'on exerce sa crēativitë entendue principalement comme capacité de réaliser une synthèse personnelle laissant voir sa vision originale sur un sujet.

It is interesting to see how this contrastive perspective leads to a definition of the essay as a relatively free-form, personal statement in which originality seems to be the key component. The French dissertation is viewed as much more rigid, impersonal, and logical.

With respect to the specific area of science writing, since the seventeenth century, with the decline in the use of Latin, there has been an awareness that science required a special use of language. The French preference for general terms stems fom this period (Darbelnet:1977,(5),2). This is also when the precision of mathematics was held up as the ideal in scientific description in England, as Sprat $(1667: 113)$, the first historian of the Royal Society, recommended that the language of members of the Society should be:

a close, naked, natural way of speaking; positive expressions; clear senses; a native easiness: bringing all things as near the Mathematical plainness, as they can.

What became known as the Newtonian approach, namely "to subject the phenomena of nature to the laws of mathematics" (Newton:1960, xvif), though admired in France, did not find its way into the language of science in France as it did in England. In a recent study of scientific and technical terminology in French and 
English, Nakos (1984:66-73) says that French "...n'a pas le même intērêt pour caractēriser les choses d'un point de vue quantitatif et énumératif que l'anglais."

\section{Similarities and Differences}

In some ways, then, English and French scientific discourse are different while in other ways they are very similar. Research which looks at types of argument structure and lexical forms has found the same differences as have been noted for the general language.

Nakos, for example, examined scientific monographs and dictionary and encyclopedia entries and concluded that French tends to use "discours cadre" more frequently than the English, meaning that French texts tend to "place" the term under discussion by prefacing it with a generalization. She also found (pp. 98-99) that the constitution of scientific text in English seemed to be more concrete and more descriptive while the French was more analytic, more abstract, better "structured," with the ideas better grouped. This led to an overall impression that the French was more logical.

One of the reasons for this impression might be a function of the syntactic restrictions on prepositional modifiers in French. In French, as in English, (Quemada:1978, 1182) techntcal language tends to create new terms by combining a generic noun with an adjective which carries the meaning: 'les notions temporospatiales' or 'spatio-temporal conceptualization' rather than 'concepts of time and space.' 2 However, technical English also tends to use noun strings, which are unusual in French and used in marketing rather than technical language. Nominal groups like 'a mail-inerge option' therefore often correspond to a prepositional phrase modifier in French ('fusionnement de variables'), or a less technical term is substituted for the learned as in this precaution in a pharmaceutical description:

There is no experience with Lopresor in the pediatric age groups.

Le Lopresor n'a pas été étudié chez les enfants. 3

Because the English in these examples violates the expectations of normal information processing, the French is clearer and easier to understand. The fact that English uses nominalizations in formal register also means that the French in this example is clearer because it conveys the message in the verb. Sublanguage research has indicated that what differentiates clinical discourse from experimental discourse in English (Sager:1986, 14) is that the latter uses significantly longer sentences and complex (i.e., embedded) modifiers. We would therefore expect that there would 
be less difference in complexity between the clinical and research discourse in French.

Where the use of figures of speech differs in French and English, it is in the narrative of scientific text, not in the way the languages create new technical terms. Both French and English--and this may be true of other languages as well--make use of analogies when coining expressions to describe new technological discoveries or processes. In other words, to get across to people how a new invention operates, the most frequently used means at first is to compare it to existing technologies. The electronics industry uses two popular sources of analogy, printing and transportation, in current explanations of how to construct on-line documentation. For example, computer users need to be able to 'leave a bookmark', i.e., find their way back to the 'page' they were on when they have to call up another screen for additional information. The technical writer is warned that users also need 'navigational signals', i.e., they need to know where a screen is located in relation to the programme, and how to get from the screen to other functions. The English term 'joystick' in computer talk was borrowed from aviation terminology. Computer terms are an example of a technology being dominated by one language group; in such cases it is likely that terms in other languages will be influenced by the source language, especially if they are derived through translation. The French term 'manche de balai' for 'joystick' was chosen because that is the aviation term used in French; in general, French metaphors would be more abstract, but the term 'manche de balai' is in fact more concrete than the English equivalent.

Since concepts are avaflable long before terms may be fixed in a second language, it is not only likely that they will follow the source language pattern, it is possfble they will be borrowed intact, as in this early text on cybernetics:

Introduire un couplage entre deux machines, c'est faire agir d'une manière ou d'une autre l'output de $l$ 'une...sur $l$ 'input de l'autre...c'est précisement ce que décrivent les généticiens lorsqu'ils affirment que la pléiotropie et la ploygēnie sont totales, l'effet d'un gène dépendant de tous ceux qui constituent son background phènotypique. ${ }^{4}$

Quemada (1978:1234) gives another reason why English technical terms tend to be used in French. Technicians use these terms-their professional jargon--frequently, and frequently used words tend to get shortened. The French term will almost always be longer than the English, and it may become vague when reduced. Quemada gives the example of the term 'taxi way' in aviation, which is 'chemin de roulage' in French and could wind up as the potentially problem-causing 'chemin'--a path or small road. 
In spite of these differences, French and English are very alike in the way they distingutsh special discourse styles for different technical and scientific fields. Kittredge (1982:129, 135) found in a comparison of six sublanguages (weather synopses, aviation hydraulics, stock market reports, recipes, pharmacology of cardiac glycocides, and an economics text) that the frequency of structures and linking devices that characterized the subianguages were remarkably similar in both languages: "...each sublanguage seems to move away from its respective language norm in the same way when cross-linguistic comparisons are made". And he commented, "This is all the more important when it is seen how wide the variation between the sublanguages of each language can be."

Here we come back to the common ideology for an explanation. Medical and pharmaceutical texts are characterized by a depersonalization. In addition, in pharmaceutical product descriptions it would be difficult to give directions to the doctor as they are given to the patient; doctors are very status conscious, and pharmaceutical texts show respect for the authority of the doctor. In both English and French, as in these examples from product information supplied by the distributor, most instructions use the third person to address the reader. When there are serious implications concerning the use or misuse of the drug, as with the warning section, modals are used in both languages to convey the urgency. French may, however, be more direct and use the infinttive, the common form for conveying instructions as in example (d).

(a) Dans certains cas, lorsque le médecin juge que son administration simultanée est essentielle, on peut instituer un traitement...

In exceptional cases, when in the opinion of the physician concomitant use is considered essential, such use should be instituted gradually.

(b) Le Lopresor est indiqué chez les patients... Lopressor is indicated in patients...

(c) Les épreuves de laboratoire appropriées doivent être effectuées....

Appropriate laboratory tests should be performed.

(d) Faire preuve de grande circonspection lors de l'administration du Lopresor. Special caution should be exercised when administering Lopresor. 


\section{Examples and Conclustons}

How similar English and French scientific rhetoric will be depends on the particular sublanguage. In a field like phamnacy, a few multinational companies dominate the industry. In an area where information is already highly formatted, there is therefore congruence in style across languages, perhaps under the influence of translation. Even advertisements, which normally have very different styles in French and English, are very similar in the pharmaceutical ads placed in trade journals directed toward doctors, such as L'Actualité médicale and Ontario Medicine. This is both because of the similarities in audience and the form of argument used to motivate sales: an underlying theme that says that the field has advanced (implying that the doctor should keep up). In general, medical research has developed an international style because there is status in publishing in English and presenting papers at world conferences. The following paragraphs describing a surgical technique came from a paper written by a Francophone, in France, and submitted for translation into English; yet there are clear signs of English influence-"significative" should go at the end of the nominal group, "en alternative" should be "comme alternative", and "attractif" should be "attrayant".

La coelioscopie post-opēratoire précoce (8ème jour) proposēe surtout par des Equipes Françaises, largement utilisēe il y a quelques annēes par de nombreux groupes, a fait une significative marche arrière: beaucoup plus rares sont ceux qui l'utilisent encore, en ayant eux mêmes restreint très nettement les indications. Personnellement je n'utilise jamais cette endoscople précoce qui n'a pas réelement fait la preuve de sa valeur significative et qui alourdit considérablement le protocole d'une chirurgie tubaire, jetant un discredit supplémentaire sur cette chirurgie qui est maintenant presque toujours discutée en alternative avec la fécondation in vitro dont le protocole est de plus en plus al légé donc de plus en plus attractif. Nous avons abandonné l'utilisation du laser C02 dont la pratique ne nous a apporté ni simplification technique, ni amëlioration statistique de nos rësultats post-opératoires.

An example of the other extreme comes from climate studies, a domain where the humanistic tradition as well as the observational/experimental may be found in French publications. The following extracts, with numbered references that illustrate the differences in discourse type, both deal with the same phenomenon, a historical study of glacial activity in Europe; the English text cites the French author and praises his work, in fact. However, the styles of the two texts are very different. The French text is extremely narrative, meaning that the elements of storytelling are accentuated, and there are other elements which make the text 
more humanistic. Reference 1 "aujourd'hui paisiblement repris par la forêt" shows the animistic tendency in French. The writer is present and empathetic as shown in 2 ("ce malheureux village"), unscientific in North American terms in the use of qualifiers in examples labelled 3 ("vaguement bifide," "bel et bien approchë"), and metaphoric in examples 4 ("couronnëe de sapins," "se perd et disparait," "les stigmates"). The English text describing the same glaciers is impersonal--reference 1 on the English text, "other attendant local disasters," "in an advancing attitude"--and unempathetic.

To sum up, it is difficult to talk about the kind of writing that characterizes science in general. There are certainly similarities in the way English and French approach science, and this is even more evident in the case of specific sublanguages which are marked by the same syntactic devices. The overwhelming influence of English in specific disciplines and technologies has led to a form of internationalization of French in which the rhetoric and terminology are in fact English. There are also differences, and these reflect different scientific and political ideologies and different traditions which are taught as academic rhetoric. These differences are consistent with published research on contrastive stylistics describing general characteristics of French and English. 
Extract from a text on climate studies, from E.L. Ladurie, 1967, Histoire du Climat depuis $1^{\prime A}$ An mil.,

Paris: Flamiorion, 124-125.

Donc, en 1616 encore, des annēes après les dēsastres qu'il a provoquēs à La Rosiēre en 1600 et 1610 , le glacier d'Argentfēre continue de "joindre"--("il est tout jouignant") les maisons de ce malheureux village, qu'il a partieltement ruiné.

Le glacier d'Argentière présente en 1616 (mais en plus accentué et en plus avancé) la forme vaguement bifide qu'il affectera encore sur une gravure de 1830 (51): une masse descend vers le villlage d'Argentière; une autre vers le hameau de La Rosière. Entre les deux jaillit le torrent sous-glaciaire: l'Arveyron ou Arbëron. Et ainsi s'explique parfaitement l'expression reprise par tous les témoins de 1616 (52) et qui a tellement intriguē Kinzl: "La rivière d'Arveyron descendant du sommet de la montagne par le milieu de deux grands glassiers (53)."

Autre mérite du texte de 1616: il rend compte parfaitement de l'actuelle configuration du terroir de La Rosière: une ancienne moraine, formẻe d'éboulis de "grosses pierres (54)", y borde en effet le hameau actuel au Nord; elle est couronnée de sapins plus que séculaires; elle marque une limite ancienne de rextension méridionale du glacier d'Argentière. Un chemin pierré, venu du N.W., se perd et disparait dans ces éboulis morainiques (55), qui l'ont manifestement coupé: 1a tradition locale, que $m$ 'a rapportée Louis Ravanel, veut qu'11 s'agisse de l'ancien chemin des Chosalets à La Rosière. Ce chemin est bordé, sur son rebord Sud et à son extrënitè Est, précisément à sa jonction avec la moraine, de soubassements quadrangulaires de murs nettement visibles et à demi enfouis dans la moraine: ruines de grangettes, adis détruites par le glacier (tradition orale, recompee par les textes de 1616 et par la topographie).

Ce terrain bouleversé, aujourd'hui paisiblement repris par la forêt, ces ruines aussi, sont très probablement les stigmates des catastrophes de 1600-1610. Et voilà confintées les assertions du dossier Crans: le glacier d'Argentière, à ses dimensions maximales de 1'áge moderne (1 (596-1616) s'est bel et bien approché non seulement du lilage d'Argentière, acis aussi, plus au sud, 11 a joint tordé La Rosière. 
Extract from a text on climate studies, from H.H. Lamb, 1985, Climatic History and the Future, paper ed., Princeton, N.J.: Princeton Untuersity Press, 8-9.

In those parts of Europe where there are glaciers there was sooner or later no doubt about the source of the troubles in the next few centuries, which have come to be known as the Little Ice Age, since the extent of ice on land and sea probably exceeded that at any other time since the last major glaciation. Ladurie (1967, 1971) has assembled a remarkable collection of reports, dated maps and pictures, which document the advances of the glaciers in the Alps and other attendant local disasters. The earliest (briefly) documented advance tells that the Vernagt glacier in the Tyrol made some initial advance quite early in the thirteenth century. 1 Archaeological study (Kinzl 1932) and recent radiocarbon dating (0eschger and Rothlisberger 1961) of the walls of a medieval irrigation course, the Oberriederin, led of from a subglacial stream emerging from the Aletsch glacier, high up in the Swiss Alps at a point which is at present covered by the glacier, indicate that the structure was destroyed by advance of the glacier some time between about A.D. 1200 and 1350--1.e. possibly as early as the first great advance of the Arctic sea ice off east Greenland. It is known from ancient documents that it was out of use by 1385 . At Grindelwald there was in 1760 (Ladurie 1971, p. 250) convincing evidence of a glacier advance about A.D. 1280 (see also footnote, p. 447), in the stumps of larch trees that had been overrun by the ice on the slopes of the Eiger and the Fisherhorn and a documentary record of a church (at Burgbiel) that was moved to be out of danger of the glacier and of floods. No more reports of glacter advance are known until the late sixteenth century, when they became numerous. A report (quoted by Ladurie 1971, p. 250) of a horseback journey by one, Sebastian Munster, from the upper Rhone valley in Switzerland over the Furka pass in August 1546, however, indicates that he crossed the Rhone where it emerged from the glacier front which was about $200 \mathrm{~m}$ across and $10-15 \mathrm{~m}$ high: the glacier was evidently al ready much farther forward than in ts cemeury and in an advancing attitude.Advancing glaciers from sidevalleys in the Alps in the following decades frequently crossed the main valley bottoms and formed ice-dammed lakes there. Thus, the Allalin glacier blocked the Saas valley in 1589 and a lake, the Mattmarksee, formed; but the ice barrier gave way in September 1589 and the lake drained in a torrential flood down the valley, a disaster that was many times repeated later, e.g. in 1633, 1680, $1719,1724,1733,1740,1752,1755,1764,1766,1772.1$ 
The ice-damined Mattmarksee was a normal feature of the Saastal landscape from 1600 until the nineteenth century; the residual lake in 1920 , dammed by the moraine formed in recent centuries, had a maximum depth of $4 \mathrm{~m}$ and held an estimated $560,000 \mathrm{~m}^{3}$ of water, to be compared with the reported $29 \mathrm{~m}$ depth and $18.8 \times 10^{6} \mathrm{~m}^{3}$ of water in 1834 . Similar disasters are recorded in many other Alpine valleys in those centuries, including in the otztal and about Chamounix on the French side (Ladurie 1971, p. 250).

Between 1530 and 1575 the inhabitants of Chamounix lamented the fact that the glaciers made their surroundings very cold, but complaints of phystcal destruction wrought by the advancing glaciers only came later. There must have been some (probably earlier) advance of the glaciers in the upper levels but no imnediate menace at that stage of the sixteenth century. But by 1580 three of the great glaciers, probably the Argentiēre, the Mer de Glace and Les Bossons, were described by a traveller as spreading through rifts in the mountains and descending almost to the valley floor. In 1600, at the time of a tax reform in Savoy, a document records that the glaciers of the Arve and other rivers had ruined much land in the parish of Chamounix, had destroyed twelve houses in the village of Chastelard (which later disappeared altogether) and that another village, Les Bois, had been left uninhabited because of the glaciers. Les Bois and another hamlet, Bonanay, also subsequently disappeared totally. In 1600 the glaciers both on the French and the Italian side of Mont Blanc had advanced so far that the people of the valleys were in panic. Ice-dammed lakes which forined and burst, as in Saastal, were the agency of much of the destruction. 
NOTES

1. Le Figaro 1ittēraire, 1964, cited in J.P. Simard, Guide du savoir-ecrire, Les Editions de l'homme: Montrêal, 1984, p. 384.

2. From Alfred Tomatis, Education et Dyslexie, p. 154 and Education and Dyslexia, P. 152 .

3. Ontario Medicine, March 5, 1984 and L'Actualitë mëdicale, March 12, 1984.

4. From Cellèrier, Papert, and Voyat, Cybernëtique et épistēmologie, Paris: Presses Universitaires de France, 1968, pp. 79-80.

\section{REFERENCES}

1. Acton, H.B. 1959. "The Philosophy of Language in Revolutionary France", Proceedings of the British Academy, 45:199-219.

2. Bernal, J.D. 1967. (originally published 1939), The Social Function of Sclence, paperback ed. Cambridge, Massachusetts and London, England: M.I.T. Press.

3. Bernhardt, S.A. 1985. "The Writer, the Reader, and the Scientific Text", Journal of Technical Writing and Communication, $15 / 2: \overline{163-174}$.

4. Cahier de mëthodologie et guide pour l'ētudiant-e, 1986. 3CeB ed., Montrēal: Universitế de Québec à Montréal.

5. Darbelnet, J. 1977. "Caractērologie linguistique", L'actualité terminologique, 10/4:1-4 and 10/5:1-4.

6. Foucault, M. 1969. L'archéologie du savoir, Paris: Gallimard.

7. Grellet, F. 1985. "The word against the word" Initiation à la version anglaise, Paris: Hachette.

8. Guillemin-Flescher, J. 1981. Syntaxe comparée du français et de l'anglais, Paris: Editions Ophrys.

9. Harris, J.S. 1984. "The Naming of Parts: An Examination of the Origins of Technical and Scientific Vocabulary", Journal of Technical Writing and Communication, 14/3:183-191.

10. Kaplan, R, 1972. Anatomy of Rhetoric, Philadelphia: The Centre for Curriculum Development Inc. 
11. Kittredge, R. 1982. "Variation and Homogeneity of Sublanguages" in R. Kittredge and J. Lehrberger (eds.): Sublanguage-Studies of Language in Restricted Semantic Domains, Berlin/New York: de Gruyter, 107-137.

12. Knight, D. 1986. The Age of Science, 0xford and New York: Basil Blackwell.

13. Loffler-Laurian, A.-M. 1983. "Typologie des discours scientifiques: deux approches", Etudes de linguistique appl 1quëe, $51: 8-20$.

14. Newton, I. 1934. Mathematical Principles of Natural Philosophy, Trans. Andrew Motte, rev. Florio Carjori, Berkeley, California: University of Callfornia Press.

15. Nakos, D. 1984. Quelques aspects des langues de spécialité en anglais et en francais, Quebec: GIRSTERM, Université Lava1.

16. Quemada, B. 1978. "Technique et langage" in B. Gille (ed.): Histoire des techniques, Encyclopédie de la Pléiade: (Vol. 41) Tours: Editions GalTimard, 1146-1238.

17. Sager, N. 1986. "Sublanguage: LInguistic Phenomenon, Computational Tool", in R. Grishman and R. Kittredge (eds.): Analyzing Language in Restricted Domains, Hillsdale, N.J. and London: Lawrence ErIbaum Assoc. 1-17.

18. Simard, J.-P. 1984. Guide du savoir-ëcrire, Montréal: Les Editions de 1 'homme.

19. Sprat, T. 1667. The History of the Royal Society of London, London.

20. Tukia, M. 1983. "Observations sur le vocabulaire, sur les marques d'énonciateur et sur la construction dans le discours scientifique, Études de linguistique appliquée, 51:34-43.

21. Vinay, J.-P. and J. Darbelnet. 1977. Stylistique comparée du francais et de l'anglais, rev. ed. Beauchemin: Montreal.

Candace Séguinot teaches in the School of Translation, Glendon college, York University, Toronto. 